\title{
Political alignments and distributive politics at the municipal level in federal countries ${ }^{3}$
}

\section{Introduction}

Distributive politics is broadly understood as the strategic allocation of public resources with electoral purposes in sight. Distributive politics across government levels is shaped by formal and informal arrangements, institutional legacies (Wibbels 2005), and redistributive pressures from various regions (Beramendi et al 2017 Calvo and Moscovich 2017) which distribute power and resources within each federation (Weingast 2013). The nested nature of federal politics results in a wide range of alliances between government levels, all of which affect distribution patterns (Dickovick 2007, Fenwick 2009, Borges 2011).

Conventional wisdom acknowledges that presidents favor governors through different channels in order to gain votes, as well as the legislative support that governors can provide, from subnational to federal arenas. In this work it is suggested that mayors also matter; alignments between presidents and governors alone do not explain distributive politics. Distribution patterns of two transfers at the municipal level will be explored in order to show that partisan

\footnotetext{
Universidad de San Andrés, Buenos Aires, Argentina Email: Imoscovich@udesa.edu.ar

Universidad Nacional de Córdoba, Córdoba, Argentina.

3 We are very grateful to Ernesto Calvo, Carlos Gervasoni, Noam Lupu and to Luis Schiumerini for their insightful suggestions. Also we thank Juan Pablo Micozzi for making an important part of the data on municipalities available. Helpful collaboration with the rest of the database building was provided by research assistants Marta Barocela, Candela Blanco Vechi, Leonela Gulizia, Marcos Meyer, Lucia Montes, Candela Naso, Natan Siking, Ana Skiendziel and Hernan Strin. Grace O'Hare and Jacob Rosemblum have worked of the edition in previous versions. We also thank a number of anonymous reviewers for the comments they have shared with us. The usual disclaimer applies.
} Revista Brasileira de Ciência Política, nº 26. Brasilia, maio - agosto de 2018, pp 63-105. 
alignments between mayors and presidents (along with other variables, such mayors being up for reelection) matter for allocation decisions.

Distributive politics matter because, when choosing one level of government to distribute resources to (and then choosing certain districts and not others within this level of government), presidents also affect electoral results and policy outcomes. They affect electoral outcomes, for instance, by making subnational democracy more competitive (Borges 2011) or by eroding clientelism (Souza 2015). More federal resources allocated in certain districts may result in higher levels of electoral support for presidents (Hunter and Power 2007, Zucco 2008, Bohn 2011). Borges (2011) showed that when governors are not aligned with presidents, alternative coalitions with mayors can increase electoral competitiveness at the state level in Brazil.

Different strategies such as (re)decentralization or distribution patterns of federal resources allow presidents to override governors (Fenwick 2009, Moscovich 2012, Dickovick and Eaton 2013). As Dickovick and Eaton describe, "national government officials have often explicitly designed policy interventions to bolster the status of the subnational level they find least threatening (i.e., municipalities), in order to check the power of the subnational level they find most threatening (i.e., states, provinces, departments, regions)" (2013: 1457). In various countries, municipalities and mayors are playing an increasing role as intermediaries in distributive politics (Gomez 2003, Dickovick 2007, Fenwick 2009, Zucco 2009, Dickovick and Eaton 2013). This paper investigates which alignments best explain the allocation of certain resources at the municipal level.

In order to understand the puzzle addressed by this work, Brazil provides a helpful example. Because states and municipalities are both federal entities in Brazil, presidents have the choice to ally with one or the other, unfolding different patterns of alliances among the three levels of governments. The objective here is to know more about distributive politics between government levels in a different type of federalism, such as Argentina where, unlike Brazil, only 
provinces are federal entities and municipalities are subordinate to them. ${ }^{4}$ This means that, first, municipalities depend on provinces for their degree of autonomy, institutional design, and territorial size. Second, municipalities results in a greater variation in the patterns of electoral and partisan competition. Third, as a result - and this is one of the crucial points in this problem - in Argentina there are fewer opportunities to override governors to deliver policies and resources to municipalities. ${ }^{5}$

If municipalities are subordinated to provinces, would the president bypass governors in order to distribute federal resources at the local level (like they do in Brazil, for instance)? Would they take the risk of undermining the power of governors (presidents' main allies) by delivering resources to mayors that are part of the opposition? Would the president distribute the same resources to each level of government, or would different resources be useful to fuel different kinds of alliances? These questions are important because in the new Argentine democracy, electoral competition has been shaped in the provincial arena. Governors have been key partners to presidents by collecting votes at the subnational level and gathering legislative support to pass laws in both federal chambers. As a result, they have important bargaining power in federal politics (Gonzalez 2016). Unsurprisingly, the key variables shaping political agreements - such as revenue sharing, partisan competition, and policy distribution - have been studied for their effects at the provincial level [i.e. lower levels of democratization of certain provinces (Gervasoni 2010), on the influence of governors over political carriers (Lodola 2009) and on institutions such as the courts (Leiras, et al 2013)] and at the federal level of government [malapportionment in federal chambers (Beramendi et al 2017) and veto power to pass important laws such as the tax-sharing

4 We thank an anonymous reviewer for suggesting that we stress this counterpoint between Argentina and Brazil in order to frame the discussion.

5 Bland stresses that "provincial administrations generally dominate their lower-level municipal counterparts, an important consideration for municipal democracy in Argentina." (Bland 2011: 86). 
regime (Ardanaz et al 2014)]. ${ }^{6}$ As a result, the power and influence of governors in Argentina is widely acknowledged. However, little is known about how presidents build their alliances with the municipalities within each province. ${ }^{7}$

To help fill this vacuum, the coexistence of different distributive patterns shaped by the presidents' choices on territorial alliances will be explored. It will be also attempted to identify how different resources are used to cement them. Using an original dataset with 17,720 observations of all Argentine municipalities (2,215 listed by the Ministry of the Interior) for a period of eight years (2002-2009), it is possible to go a step further, scrutinizing the distribution variation of the Argentine federal government's assistance programs through the lens of political alignments among presidents, governors, and mayors. The programs chosen are: one workfare program and one emergency housing program. Both are allocated with a high level of discretion, but they differ in their policy goals. Decisions that deliver resources to certain districts and the amount given follow different patterns depending on political and social variables, as well as the type of resources delivered.

These findings contribute to the burgeoning literature on the relationships between government levels, both in unitary and federal countries (O’Neill 2005, Dickovick 2007 and 2014, Borges and Lloyd 2016). Particularly, they focus on the role of distributive politics in changing the balance of power among government levels (Eaton 2004, Fenwick 2009, Souza 2015, Borges 2011) and local democratization (Zucco 2009).

6 For a complete literature review of works addressing these issues at the intermediate level of government and their influence in federal politics in Argentina, see Ardanaz et al. (2014).

7 Municipal politics have been approached primarily through the lens of clientelistic practices, assisting both presidents and governors in the collection of votes across election types (Auyero 2001, Stokes et al. 2013, Szwarcberg 2013, Zarazaga 2014). A number of qualitative case studies of municipalities and local governments study several aspects of politics (i.e. Pirez 1991b, Chiara and Di Virgilio 2005, Moscovich 2008). There are also studies on the political economy or distributive politics using data from several municipalities for just one year or within a few provinces (Porto and Porto 2000, Nazareno et al. 2007, Stokes et al. 2013). Lodola (2005) includes mayors' parties to explain distribution patterns of a workfare program; however, the dependent variable considered is expenditure by province. To the best of our knowledge there are no time series empirical analyses, even on federal expenditures, for all Argentine municipalities. 
The focus lies on the resources and opportunities that create various patterns of distributive politics at the municipal level. What makes this strategic allocation possible is the availability of resources that presidents can deliver with discretion. This discretion allows presidents to use resources in order to seek support given different incentives - for instance when a president seeks different partners to strengthen his position, as president Nestor Kirchner did when he got to office with a weak electoral performance. Section III explains why partisan alignments with governors and mayors are considered a good proxy for the diversity of alliances among government levels. As section IV explores, governors are presidents' main partners in federal countries, but the alliances between presidents and governors explain only a part of the funds delivered to municipalities. In Argentina, mayors also play an important role in federal politics, but municipalities are subordinated to provinces, presenting an interesting puzzle worth analyzing. Section IV zooms in on the determinants of these distribution patterns. In section IV it is developed the hypotheses regarding the influence of presidents' alliances with governors and mayors, as well as the type of resources delivered in distributive politics at the municipal level. Section V presents the variables to be examined, and Section VI shows that distribution does vary according to partisan alignments among different levels of government. Mixed evidence regarding the second hypothesis on distribution patterns differing by types of resources can be found. In section VII lies the final remarks.

\section{New tools and opportunities for distributive politics among government levels}

Distributive politics, understood as the strategic allocation of resources with political purposes, relies on the discretion with which these resources can be distributed among a set of potential beneficiaries. For instance, formula grants give incumbents little 
flexibility and discretion. ${ }^{8}$ Working with these grants would offer little information about the strategic allocation of these resources. The president has access to federal resources that can be delivered with discretion across government levels, such as social safety net programs (workfare programs, social assistance programs, emergency housing programs and, sometimes, conditional cash transfers). As a result, the presidents' choices are explored by studying the distribution of two different federal transfers from social programs. The distribution of these two programs at the municipal level in Argentina in the period from 2002 to 2009 is the dependent variable.

Social assistance policies have been used as proxies for the federal government's coalition-building strategies when the federal government distributes these funds in favor of one level over another (Fenwick 2009), such as municipalities (Dickovick, 2007). In addition, resources delivered at the subnational level can be used to strengthen the federal government's position through other subnational units (Dickovick and Eaton, 2013). In other cases, resources delivered with high discretion - such as cash transfers - are backing the partisan strategy of central government in order to build the basis for its electoral success (Hunter and Power 2007).

In Argentina, changes in social assistance since the mid-1990s (Lodola, 2005), particularly since the 2000s, have created new tools for presidents to seek votes at the municipal level. Social assistance programs, workfare programs, and, to a lesser extent, conditional cash transfers can be distributed with discretion, allowing the federal government to reach both governors and mayors (and voters through them). These social policies make coalitions feasible, easier to fuel and, as a result, attractive. Nazareno et al. (2007) show how workfare program funds are delivered to municipalities

8 The Coparticipación (the federal formula grant tax-sharing regime) is the main source of transfers from the federal government to the provinces. Several works suggest its high complexity; the regime of exceptions and the margin for political bargaining subvert its automatic allocation of resources, giving the president a certain degree of discretion, and thus affecting its distribution (Porto and Sanguinetti 2001, Tommasi 2002). Unlike Brazil, there are not fixed transfers of the tax-sharing regime to municipalities. 
targeting swing districts, and are more effective than public employment (patronage) in collecting votes. ${ }^{9}$ With a representative sample of 127 municipalities, Weitz-Shapiro (2012) suggests that mayoral intervention in the distribution of welfare benefits - alongside the lack of opposition - promotes clientelism in Argentina. Overall, for presidents, the stability of political networks in municipalities increases the opportunity to control voters' behavior and demonstrates the importance of smaller districts in vote seeking strategies.

Although throughout the years Peronism split definitively, during this period we analyze Kirchner's faction was one more within the party. In other words we analyze the Frente para la Victoria as one more faction within the peronist party, and not as a different electoral alternative. ${ }^{10}$ Nestor Kirchner supported several candidates running for the same positions in different government levels, even when these candidates did not belong to the President's electoral coalition. Moreover, these new territorial agreements also included politicians from his main opposition parties (even in districts with core allies as incumbents), social organizations, and also mayors. Before Kirchner, bypassing allied governors to reach mayors was rare (except in the most populated counties in the Buenos Aires metropolitan area). ${ }^{11}$

The diversification of allies at the subnational level was mostly a result of Kirchner's political weakness during his first years of government, but the lack of trust in his own party partners also made such diversification necessary. Thanks to its sustained growth and

9 The 2007 election saw 56\% of municipalities reelect their mayors.

10 Although throughout the years Peronism split definitively, during this period we analyze Kirchner's faction was one more within the party. In other words we analyze the Frente para la Victoria as one more faction within the Peronist party, and not as a different electoral alternative.

11 The Argentine federal government started to intervene in the most populated municipalities when the constitutional reform of 1994 permitted direct votes to elect presidents. Ardanaz et al. suggest: "There are also instances of the president trying to circumvent the province and going directly to the lower level of government, the municipalities. But even that channel is conditional on the strength of the grip of the governor. If the majors of most important municipalities are aligned with the governor, such 'bridging' will not take place." (2014: 42). While this was the main pattern in the past, presidents now also bridge governors in municipalities aligned with them. 
resource availability, ${ }^{12}$ the federal government was able to unfold a series of social programs targeting the poor at the county level, becoming part of the regional trend of implementing non-contributory tools for social assistance.

\section{Determinants of distribution}

It is suggested that distributive politics are conditioned by the use that presidents give to these programs: to cement alliances with (or to reward) mayors and governors. This does not mean that these policies are used only for electoral purposes. The policies have specific aims, such as to alleviate people's needs and to achieve certain policy designs. Everything matter in order to understand which levels of government benefit most from these payments. Political, partisan and programmatic concerns explain why municipalities get these programs, as well as why some of them get more than others.

It is explored, specifically, the influence of partisan alignments between presidents and governors or mayors in distribution patterns . Partisan alignments across government levels are dummy variables combining all possible alignments between mayors, governors and presidents. It is expected a variation in patterns of revenue distribution depending on these alignments, the main independent variables.

In this sense, the second generation of studies in fiscal federalism underscore how relations among government levels shape distributive politics and affect, for instance, local development. In the words of Weingast (2015), this is important in developing countries where local public goods are financed by federal resources delivered with high discretion. These resources are used as a way to compel citizens to vote for the political party that distributes them.

12 Several economic policies increased the access of the federal executive branch to funds without the control of Congress or governors. Some of these measures were linked to the nationalization of the pension system in 2008. In addition, an estimated 30 billion dollars and the reform of the Central Bank Charter in 2012 allowed the federal government to use monetary reserves for up to $12 \%$ of the monetary base with financial aims. In addition, the federal government controls $70 \%$ of soybean export taxes. 
According to Weingast, the threat of withdrawal if they change their vote leads citizens to support the incumbent party.

Alignments explain distribution, from federal to subnational governments. Distribution guarantees subnational governments the resources to fuel local control. Mayors and governors must tightly control local politics in order to give presidents the political inputs that local politics can provide to federal politics (votes, candidates, policy networks, and legislative support). Evidence from Brazil suggests that presidents fuel coalitions by "building strategies in settings characterized by a persistent coincidence between the parties and/or coalitions occupying at the same time the federal and state governments" (Borges 2011: 32) ${ }^{13}$ This party alignment guarantees governors access to resources that finance their political activities - i.e. patronage (Murillo and Calvo, 2004) - and deliver particularized favors and resources to buy votes for elections. Party alignment helps to prevent the opposition from building alternative coalitions with the president (Borges, 2011). The absence of these alignments means that governors risk the rollback of their monopoly over resources.

One of the tools that presidents have to override non-allied governors is to deliver resources to municipalities, thus undermining their power (Fenwick, 2009). For mayors, alignments with successful presidential candidates allow them to avoid electoral defeat when facing opposing governors (Borges 2011, Borges and Llloyd, 2016) ${ }^{14}$ Freille and Capello (2014) verified a negative correlation between locally-collected resources and reelection at the municipal level. They suggest that the lower the weight of locally-collected resources in the municipal budget, the higher the chances of mayoral reelection, and that locally-collected resources have a negative correlation with the success of the incumbent party. Carlos Gervasoni reaches similar conclusions at the provincial level when analyzing the effects of federal transfers to governors. In both works

13 For the use of political alignments in distributive politics, see Niedzwiecki (2015).

14 Simultaneous elections result in a coattail effect where mayors opposing successful governors or presidents are prone to failure (Carson and Roberts 2013, Meredith 2011, Samuels 2003). 
the logic is similar. Both for mayors and governors, counting on resources without paying the cost of collecting them reduces the incentives for citizens to try to affect how the government spends its money. On the other hand, it gives more resources to politicians that can be used for electoral purposes. Boulding and Brown (2013) put forth the same conclusion: they suggest that more resources predict lower levels of electoral competition and higher levels of turnout at the municipal level. Using evidence on social spending in Brazil, they find a positive correlation between more money being available for mobilizing voters and higher margins of victory for incumbents. Counting on more or fewer resources affects the chances of winning or losing votes. The federal government knows this; therefore, distributive politics follow certain patterns in order to reward core or swing governors and mayors depending on their strategies. These mechanisms account for the inclusion of a number of variables, which serve as proxies for the competitiveness level of municipalities and provinces. Mayors' reelection, margin of victory (provincial), malapportionment (provincial), and effective number of parties (provincial) are control variables used to assess this control over local politics and are explained below in section V. In this section, it will be explained the nature and use of the distributive politics of workfare programs in relation to partisan alignments; then, in the following section, there is a zoom in on the determinants of these distribution patterns.

\section{Explaining distribution to subnational districts: the choice for governors and mayors}

As mentioned above, in Argentina, unlike Brazil, municipalities are not autonomous. They depend on governors, therefore presidents see governors and mayors as "asymmetric partners." Given this different status as federal entities and the power of governors, one wonders whether mayors also matter for distribution decisions. Argentina provides an ideal setting to study these different coalition patterns. It is a federation with one federal district, 23 provinces, 
and more than 2,200 municipalities, and for reasons explained below, both governors and mayors matter in federal politics.

Why are presidents' relationships to governors and mayors so different? Presidents build different alliances to maximize political outcomes from each district. Both governors and mayors (from the most populated districts) can help presidents gain votes and mobilize people to rally support for the national government's causes. ${ }^{15}$

Governors oversee politicians' careers and instruct legislators from their districts to pass certain laws in national chambers (De Luca 2008, Ardanaz et al., 2013). Mayors usually lack this influence on political careers, but they can become legislators - or other prominent figures in federal politics - themselves. Municipalities are a necessary step in a politicians' careers, before (Lodola 2009) or after (Samuels,2003) politicians' tours of duty in the national chambers or cabinet.

Electoral mobilization relies on governors and their control over provincial party branches (De Luca 2008). They facilitate parties' access to public funds for organizational purposes, such as money and logistics for electoral campaigns or public employments for party members (Calvo and Murillo, 2004). Governors remain in power by reallocating discretionary federal funds to build their patronage base ${ }^{16}$ and tightly controlling several aspects of public life and of the provincial economic realm (Gervasoni, 2010, Behrend, 2011). Governors are, thus, identified as responsible for the fate of their provinces (Gonzalez 2016). However, at the same time, the provinces depend on federal resources and experience high vertical

15 Several works account for the blurred boundaries between policy delivery and support-rallying or vote seeking (Auyero 2001, Stokes et al. 2013, Szwarcberg 2013, Zarazaga 2014, Camp and Szwarcberg 2015). However, our central focus is to explore patterns of distribution emerging from presidents' choices. It is beyond the scope of this work to identify how these funds are used once governors and mayors receive them. Thus, we adopt the concern of Gonzalez (2017), who suggests that social spending must not be approached only through the lens of clientelism, and that patterns of distribution themselves are worth considering. This is particularly due to the difficulty of observing the real effect of money delivered on voting behavior and the more general complexity involved in measuring clientelism (2017: 94).

16 Governors belonging to the president's party receive additional funds, as occurs in Brazil (Borges 2011). 
fiscal imbalance (Jones et al. 1998, Meloni, 2010), making federal resources crucial for governors.

Municipalities in Argentina are subordinated to provinces (Bland, 2011) and lack self-generated policies, tools and resources, making them dependent on the provincial and federal governments. However, this does not mean that they do not matter; they contribute with their own control over local politics. Mayors distribute funds at the municipal level through party machines and brokers to mobilize voters for elections and rally support for presidents (Szwarcberg, 2013). However, municipalities lack constitutionally-guaranteed revenues. ${ }^{17}$ In addition, they can only collect limited taxes, which vary across districts. The paradox of local mobilization in Argentine municipalities is that mayors lack resources to fuel their party machines, creating a mutual dependency upon federal transfers. The government level that distributes federal grants exerts greater influence upon local politics than other levels of government that do not distribute these grants (Weitz-Schapiro, 2012).

Although governors are often responsible for resolving people's needs with specific policies or employing people in the provincial state apparatus, mayors are responsible for street-level bureaucrats who ensure that federal and provincial policies reach their intended beneficiaries (Garay, 2007, Fenwick, 2010). Many policies (local, provincial, or federal) are delivered to citizens at the municipal level; thus, municipal collaboration can help the federal government pursue its policy goals (Fenwick, 2009). In fact, mayors are in the best position to help the federal government deliver conditional cash transfers (Fenwick, 2009), thanks to their closer access to citizens and ability to identify potential beneficiaries (Weitz-Schapiro, 2012). Therefore, mayors often facilitate outcomes such as vote seeking, candidate selection, policy delivery, political mobilization, and social peace, regardless of the governors.

17 While for Fenwick (2009) institutional and economic autonomy is crucial in order to explain why presidents override governors in the delivery of social programs, in Argentina lower levels of municipal autonomy render this explanation unsuitable. 
Governors and mayors contribute with the necessary political inputs to federal politics and the president may have no incentive or choice to remove them. However, when they have money to distribute with discretion, presidents do not allocate it uniformly within all provinces and its respective municipalities. There are differences in the money allocated to different provinces and, within them, to different municipalities. These alliances require the use of specific resources.

Therefore the hypotheses to be tested are:

1) Governors are presidents' main partners at the subnational level. However, it is suggested that presidents also need mayoral collaboration, and similar to the provincial level, this collaboration is fueled by distributive politics. Therefore, beyond governors, alignments between presidents and mayors in addition to mayoral reelection (as a proxy of the control that mayors have over their territories) will be important to identify the determinants of distributive politics.

2) Given the patterns of alliances that explain distribution to provinces and municipalities within those, different types of transfers allow presidents to build alliances with different subnational political players.

2.a) It is also suggested that highly individualized transfers are preferable for delivery to mayors, who are able to control their districts and approach citizens on an individual basis. These programs do not require any specific expertise or administrative state capacity for their reallocation.

2.b) Public works such as infrastructure, roads, and housing are used to reward governor support, and governors prefer them to bolster their image with citizens.

\section{Political and social determinants of distributive patterns with mayors and governors}

In this section, the focus lies on the operationalization of variables, along with their supporting data. Tables with descriptive 
statistics and a complete list of variables with their definitions and sources can be found in Appendices A and B.

\section{Dependent variables}

The dependent variables consist of two different federal social programs distributed in Argentine municipalities. The president has access to federal resources that can be delivered with discretion, such as social safety net programs (workfare programs, social assistance programs, housing emergency programs and, sometimes, conditional cash transfers) across various levels of government. Discretion allows them to build alliances with different players. Neither provinces nor municipalities can ask for exclusivity in their relations with the federal government. This means that governors cannot prevent mayors from receiving resources as well. The dependent variable, then, is whether a municipality received resources from these programs (models 1-4) and the log of the total amount received by a municipality from one of these programs' transfers (models $5-6) .^{18}$

The first program considered is the Emergency Housing Program (EH), created in 2003. In order to be aware of the program, beneficiaries had to keep some kind of contact with municipal governments or political networks. Second, each beneficiary needed to become a member of (or create) a cooperative, with which he or she would continue to work under the program for an extended period of time. Members received a salary for their work, resources for basic supplies, and had to coordinate the administration of the funds for building materials with their respective municipalities. ${ }^{19}$ The $\mathrm{EH}$ program had direct and indirect beneficiaries. Direct beneficiaries were the members of the cooperatives $(86,400$ members were employed). The indirect beneficiaries $(4,338,000$ people) consisted of all people living in the neighborhoods that benefited from construction work (data provided by functionaries from the Ministry of

18 See below for further details about the models.

19 Although from these last two features, one can expect this program to be useful to fuel alliances with mayors, we will see that presidents prefer to deliver them to both governors and mayors. 
Federal Planning, Public Investment and Services in 2010). Various criteria informed the allocation of houses and resources. Sometimes there was a waitlist for a house in the municipality, while in other cases, members of cooperatives (and/or wider social organizations holding the cooperatives) had priority in the assignment of new houses.

The second program is the $\mathrm{PJJH}$ ( household heads program, or Plan Jefes $y$ Jefas de Hogar), which was created in 2002 and soothed social discontent after the 2001-2002 crisis. Program implementation was advertised nationwide, and requirements to qualify were widely known: only unemployed people with children under 18 years old were eligible. It reached a great number of people and enrollment lasted just two weeks in May 2002. There was little room for discretion: all eligible people joined and local councils, under the control of civil society, monitored its distribution at the municipal level. After ceasing the enrollment, one could only join the program if someone else dropped out. Later on, it turned out to be a helpful tool for discretionary allocation used by municipal governments and social organizations (such as 'Piqueteros'). Both were also responsible for monitoring beneficiaries for the number of weekly hours they had to work in order to continue receiving the benefit. The number of beneficiaries decreased over time as people changed workfare programs [for instance, $44.8 \%$ moved to another program called Familias (MTSS 2009)] or found jobs. Enrollment dropped from almost 2,000,000 beneficiaries in 2003 to around 700,000 in 2008 (MTSS 2009).

These two programs differed in goals, scope and allocation methods. Their scope and timing moved in opposite directions. People living in $91 \%$ of the municipalities in the database received $\mathrm{PJJH}$ and just $8 \%$ received $\mathrm{EH}$. While the $\mathrm{PJJH}$ was at its highest enrollment at the beginning of the period studied, EH enrollment increased over the years. It is expected that the president would deliver the policies more appreciated by each partner (governors or mayors). The fact that the programs chosen differed in several ways will allow us to test these hypotheses. At the same time, they are 
also comparable because of two important coincidences: in almost all cases the programs were transferred from the federal executive to beneficiaries at the municipal level, and beneficiaries needed to be connected to territorial partisan networks to take part on $\mathrm{EH}$ or PJJH.

\section{Independent variables}

For the models, two different groups of independent variables were employed. The first group consists of partisan alignments between government levels (whether mayors, governors and presidents belong to the same party or not), for models 2, 4 and 6 . They are used as proxy for these twofold distributive patterns with mayors and governors. Partisan alignments across government levels make up a group of dummy variables combining all possible alignments among mayors, governors and presidents. It is expected to find a variation in patterns of revenue distribution depending on these alignments. In some models the alignment was replaced for a second group of variables - mayors' parties - in order to understand how these patterns are affected by mayors' partisanship, beyond their alignment with presidents (models 1, 3 and 5).

\section{Political Control Variables}

Mayors' reelection, margin of victory (provincial), malapportionment (provincial) and effective number of parties (provincial) are control variables used to assess this control over local politics. The influence of reelection in distribution patterns was tested. The mayors' names in four different elections were used in order to assess reelection trends (even if they changed party). Reelection can be considered a measure of incumbent advantage, explaining distributive politics in favor of mayors who are able to keep their power. If reelection increases the chances of getting money, as well as the quantity of money given, then presidents should reward successful mayors who keep a tight control over their networks.

Other control variables assess competitiveness in gubernatorial elections. Governors' margin of victory over challengers in previous 
elections and effective number of parties (Laakso and Taagepera, 1979) running in provincial elections provide valuable information on the level of provincial polities' competitiveness. In addition, this influences the odds of getting workfare programs - and the amount of funds received - for each municipality. Another political control variable is malapportionment. Argentina is the federation with the highest rate of imbalance between numbers of voters per seats in chambers (Samuels and Snyder 2001); this has a number of consequences for coalition building and legislative support seeking. Governors of poorer and less populated areas can be "cheaper" to persuade [what Gibson and Calvo (2000) called the peripheral coalition]. Transfers from a small housing program can be seen as marginal or less valuable for governors. As Lee (2003) suggests, a smaller transfer can be more visible and have more impact in a smaller district. These districts are also likely to engage in federal coalitions and Gordin (2010) shows that presidents use discretionary funds and bilateral agreements (fiscal pacts) to assert their veto power in federal chambers.

\section{Socio-Demographic Control Variables}

Since both revenues used as dependent variables were meant to target the poor, social variables were included in the models as controls. These control variables allow one to assess the weight that programmatic distribution has vis a vis tactical allocation. Spending is related to political competition and programmatic considerations as well (Gonzalez, 2017), since, for instance, poorer areas are more sensitive to patronage and clientelism. Unfortunately there is no information available at the municipal level for all the years covered by this study; the Census information for poverty (log of people with basic unsatisfied needs) in all municipalities and lagged provincial unemployment rates for all the years in the series were employed. Workfare programs tend to be allocated to people who most need them; it can be verified that the distribution of social cash transfers and public works for the poor are determined 
by social variables. ${ }^{20}$ However, since there are more poor people than resources to be delivered, evidence demonstrates that even among the very poor, discretion favors clientelistic distribution on a political basis (Giraudy, 2007). This is due not only due to clientelism, but also to the presidents' objective to persuade more discontented voters as a result of their precarious situation (Zucco, 2008). Therefore, it is suggested that high levels of fiscal imbalance, both at the provincial and municipal level, make federal resources more valuable, particularly in less developed regions. For these reasons, distribution patterns of workfare programs are expected to be affected by social variables as well.

Lastly, the population log was controlled (at the municipal level for 2001). The literature does not agree on the potential effects of population in vote seeking and distributive politics. This is because, on one hand, more populated districts may seem more valuable for vote seeking and, on the other hand, smaller and less populated districts can also be attractive because they are over-represented and cheaper to include in an alliance (Gibson and Calvo 2000). Some research has shown that smaller localities are more prone to the clientelistic control by brokers. In the next section the results and its interpretation are disclosed.

\section{Data and Models}

In federal countries, presidents need both mayors and governors, and they use specific policies to build alliances with both of them. Presidents can use different alignments in order to distribute different types of funds. This statement will be explored by using an original dataset with 17,720 observations of all Argentine municipalities (2,215 listed by the Ministry of the Interior) for a

20 In Brazil, for instance, the political distribution of conditional cash transfers among supporters at the municipal level did not hinder the achievement of this policy outcome (Zucco 2008, Fenwick 2009). 
period of eight years (2002-2009) ${ }^{21}$ with the intention of identifying distribution patterns of federal revenues at the municipal level. For each municipality we use the amount of money received from the following two different revenue sources - a workfare program and a housing program - and a number of political and social variables (all described above).

First, four logistic regressions for cross-sectional time series data were specified and then the above-mentioned revenues were assessed (models 1-4). In these models, the dependent variables are two dichotomous variables that assume the value of 1 if a municipality in a particular year obtains a transfer from the $\mathrm{PJJH}$ or $\mathrm{EH}$ and 0 otherwise ${ }^{22}$.

Then, a general square regression for panel data was performed to understand why some municipalities receive more of one these transfers (models 5-6). In these models, the dependent variable is a continuous variable consisting of the total money from the PJJH given to each municipality each year, logged. ${ }^{23}$

The main independent variables are all possible combinations of party alignments among the three government levels (Models 2, 4 and 6). Different government levels were considered as aligned when belonging to the same political party or electoral coalition at election time (Borges 2011). In order to address the effects of partisanship beyond alignments in models 1, 3 and 5, mayors' party

21 Néstor Kirchner took office in 2003, but 2002 data was employed as well because the PJJH started that year. After the 2001 crisis, interim president Eduardo Duhalde mentored Kirchner. Kirchner was Duhalde's presidential candidate and some members of Duhalde's cabinet remained in office after 2003.

22 Where $X$ is a vector of control variables: reelected mayor, margin of victory, ENCP, malapportionment, provincial unemployment (lagged), poverty, population, other party mayor, provincial party mayor, Peronist party mayor, and UCR party mayor.

23 Our main concern is what makes a municipality eligible for a president to deliver money. For this reason, both programs were regressed with logits in order to explore why a municipality was chosen. However, since the PJJH went to $91 \%$ of municipalities, it was also necessary to provide further details on what make a municipality get more resources than others. Therefore, the PJJH was also regressed using general square regression. The model produces estimators that were unaffected by autocorrelation and heteroscedasticity. This is useful when datasets have fewer time components than districts, provinces, and municipalities (Gonzalez 2017). 
were used instead of party alignments. For all models, random effects wee employed. ${ }^{24}$

\section{Results}

The results show that presidential alliances with mayors and governors coexist. However, the latter remain more influential in the decisions of tactical allocations of federal resources, which is consistent with the asymmetric nature of the partnership: governors are more powerful than mayors and bring presidents more political inputs. Social variables also have a positive and significant influence on the distribution of one of the workfare programs analyzed. Funds go to municipalities with poorer people (Zucco, 2008). But, since there are fewer resources than eligible people within the poor, political variables also intervene in its distribution. Within those political variables, alignments among government levels are more influential than competitiveness in the last gubernatorial elections, malapportionment at the provincial level, or the party to which the mayor belongs.

Given the array of political coalitions presidents may build in multilevel polities, they try to maximize the returns of their investments in both municipalities and provinces. Both alignments between president-governor and president-mayor alliances significantly explain the allocation of the housing program in question (models 1 and 2). However, governors play a stronger role in the municipal attainment of this resource. This makes sense for two reasons: first, governors play a role as counterparts of the federal government in public works, and second, these governors get rewards from the visibility of these public works [not excludable goods (Calvo and Murillo, 2013)] at the provincial level.

Alignments with the president's party significantly explain the distribution of this program. If one considers the mayor's party

24 The models were implemented both with random and fixed effects. For both specifications, coefficients kept their signs. However, the models with random effects were chosen because some variables did not change in time and were dropped when assessed with fixed effects. For the advantages of using random effects and its application to Generalized Least Squares (GLS), see Williams (2017) and Gonzalez (2017). 
alone without the alignments (model 1), the influence is weaker. ${ }^{25}$ Mayors' alliances with presidents increase the chances of getting the $\mathrm{EH}$ by 1.5 times. However, when governors share the party with the president, the chances of getting the $\mathrm{EH}$ are 3 times higher. Municipalities from the FPV had more chances of receiving these workfare programs. Mayors from other parties and particularly from the UCR had significantly lower chances of getting the EH.

Beyond political variables, a number of demographic and social variables capture the balance between programmatic and distributive politics. How much do social indicators affect patterns of distribution vis a vis other political variables? Population has a very small and negative influence when political alignments are included (models 1 and 2). When included, political variables (such as alignments between presidents and governors) capture the effects of sociodemographic variables, such as population, on a municipality's likelihood of receiving this program. It can be inferred that this housing program is delivered with political, rather than programmatic, purposes.

Poverty has a small influence on the chances that a municipality receives the $\mathrm{EH}$. The coefficient for poverty is similar to that for political alignments. If governors are so influential in the allocation of the EH to a given municipality, why do mayors (and which mayors) also matter? Thanks to this program, unemployed workers are organized in cooperatives to build houses for the poor. Beneficiaries of the housing program receive a salary for construction work and once the houses are finished, they are given to people who lack proper housing (whether or not they are members of the cooperatives). On one hand, public works are useful for governors to claim credit, and the province has the administrative capacity to help beneficiaries access construction materials. However, county-level personal networks managed by mayors remain crucial in its implementation, since they help federal government identify cooperative members and housing recipients.

25 This is consistent with Gonzalez's (2017) findings about the weak influence of governors' parties in determining social spending at the provincial level. 
In the same vein as previous findings in the literature (Nazareno et al. 2007, Calvo and Murillo 2013, Posner and Kramor 2013), it is suggested that each transfer can serve different goals, particularly those aimed at building a variety of coalitions with mayors and governors. Since the president has enough resources for different allies, he or she has no incentive to leave aside any intermediary in subnational territories. Instead, presidents can choose which transfer to deliver in order to fuel a particular coalition, overriding governors if necessary. Public works are highly visible for all voters of the province, whether or not they are the direct beneficiaries of a particular workfare program; this housing program is useful to cement alliances with governors and also (to a lesser extent) with mayors.

Table 1 - Municipalities Receiving Federal Transfers for Housing and Workfare Programs

\begin{tabular}{|c|c|c|c|c|}
\hline Variables & 1EH & 2EH & 3РנJH & 4PJJH \\
\hline \multirow[t]{2}{*}{ Mayor aligned with Governor } & \multirow{2}{*}{-} & -0.2169209 & \multirow{2}{*}{-} & 0.4619788 \\
\hline & & $(-0.3527)$ & & $(-11.806)$ \\
\hline \multirow[t]{2}{*}{ Mayor aligned with President } & \multirow{2}{*}{ - } & $0.4576046^{*}$ & \multirow{2}{*}{ - } & 0.7454973 \\
\hline & & $(-0.2511)$ & & $(-0.6502)$ \\
\hline \multirow[t]{2}{*}{ Governor aligned with President } & \multirow{2}{*}{ - } & $1.068727^{* * *}$ & \multirow{2}{*}{-} & $1.70575^{*}$ \\
\hline & & $(-0.2843)$ & & $(-0.9971)$ \\
\hline \multirow[t]{2}{*}{ Full alignment } & \multirow{2}{*}{ - } & 0.0335183 & \multirow{2}{*}{ - } & -0.8017372 \\
\hline & & $(-0.5666)$ & & $(-17.566)$ \\
\hline \multirow[t]{2}{*}{ Reelected Mayor } & 0.2206179 & 0.0122117 & 0.4096745 & $1.054066^{* * *}$ \\
\hline & $(-0.1546)$ & $(-0.1411)$ & $(-0.4412)$ & $(0.3832)$ \\
\hline \multirow[t]{2}{*}{ Margin of Victory } & $0.0162436^{* * *}$ & $0.0092529^{* *}$ & $-0.0365913^{*}$ & $-0.0330705^{* *}$ \\
\hline & $(-0.0048)$ & $(-0.0045)$ & $(-0.0209)$ & $(-0.0149)$ \\
\hline \multirow[t]{2}{*}{ ENCP } & -0.1402742 & 0.0873193 & $-2.026349^{* * *}$ & $-1.838069^{* * *}$ \\
\hline & $(-0.1427)$ & $-(0.1329)$ & $(-0.7770)$ & $(-0.5242)$ \\
\hline \multirow[t]{2}{*}{ Malapportionment } & $-1.41597^{* * *}$ & $-1.449142^{* * *}$ & $-2.472801^{* *}$ & $-3.324537^{* * *}$ \\
\hline & $(-0.3247)$ & $(-0.3072)$ & $(-10.347)$ & $(-0.9896)$ \\
\hline \multirow[t]{2}{*}{ Provincial unemployment (lagged) } & 0.0071549 & 0.0258674 & -0.0119932 & -0.0460234 \\
\hline & $(-0.0310)$ & $(-0.0301)$ & $(-0.0813)$ & $(-0.0721)$ \\
\hline Poverty & $1.926839^{* * *}$ & $2.024774^{* * *}$ & $5.8851^{* * *}$ & $3.96413^{* * *}$ \\
\hline
\end{tabular}




\begin{tabular}{|c|c|c|c|c|}
\hline & $(-0.2423)$ & $(-0.2349)$ & $(-0.7016)$ & $(-0.9973)$ \\
\hline \multirow[t]{2}{*}{ Population } & $-0.3863056^{*}$ & $-0.5391375^{* * *}$ & $2.09829^{* * *}$ & $4.162032^{* * *}$ \\
\hline & $(-0.2144)$ & $(-0.2065)$ & $(-0.7092)$ & $(-10.398)$ \\
\hline \multirow[t]{2}{*}{ Other Party Mayor } & $-1.779833^{* * *}$ & \multirow{2}{*}{-} & 0.2040363 & \multirow{2}{*}{ - } \\
\hline & $(-0.3671)$ & & $(-0.9195)$ & \\
\hline \multirow[t]{2}{*}{ Provincial Party Mayor } & -0.4799875 & \multirow{2}{*}{-} & 0.006082 & \multirow{2}{*}{-} \\
\hline & $(-0.3267)$ & & $(-12.008)$ & \\
\hline \multirow[t]{2}{*}{ Peronist Party Mayor } & -0.2155735 & \multirow{2}{*}{-} & 0.7738508 & \multirow{2}{*}{ - } \\
\hline & $(-0.2571)$ & & $(-0.7775)$ & \\
\hline \multirow[t]{2}{*}{ UCR Party Mayor } & $-1.33772^{* * *}$ & \multirow{2}{*}{-} & -0.1439882 & \multirow{2}{*}{-} \\
\hline & $(-0.3207)$ & & $(-0.9228)$ & \\
\hline \multirow[t]{2}{*}{ Year 2003} & $-4.900659^{* * *}$ & $-5.36451^{* * *}$ & -0.4423635 & $-0.996553^{*}$ \\
\hline & $(-0.5109)$ & $(-0.4872)$ & $(-0.6805)$ & $(-0.5784)$ \\
\hline \multirow[t]{2}{*}{ Year 2004} & $-3.005545^{* * *}$ & $-3.366439 * * *$ & -0.7505732 & -0.7293322 \\
\hline & $(-0.3605)$ & $(-0.3218)$ & $(-0.6837)$ & $(-0.5937)$ \\
\hline \multirow[t]{2}{*}{ Year 2005} & $-1.608541^{* * *}$ & $-2.146501^{* * *}$ & -0.9510846 & -1.259 .131 \\
\hline & $(-0.3351)$ & $(-0.2906)$ & $(-0.8245)$ & $(-0.7823)$ \\
\hline \multirow[t]{2}{*}{ Year 2006} & $-0.7215922^{* * *}$ & $-1.036442^{* * *}$ & $-1.94352^{*}$ & $-2.413602^{* *}$ \\
\hline & $(-0.2656)$ & $(-0.2230)$ & $(-10.480)$ & $(-0.9548)$ \\
\hline \multirow[t]{2}{*}{ Year 2007} & -0.0963235 & -0.0131609 & $-2.983259^{* * *}$ & $-3.099258^{* * *}$ \\
\hline & $(-0.2049)$ & $(-0.1694)$ & $(-0.8090)$ & $(-0.7017)$ \\
\hline \multirow[t]{2}{*}{ Year 2008} & -0.2051158 & $-0.3075989^{* *}$ & $-2.880066^{* * *}$ & $-3.234865^{* * *}$ \\
\hline & $(-0.1579)$ & $(-0.1534)$ & -10.328 & $(-0.8472)$ \\
\hline \multirow[t]{2}{*}{ Year 2009} & \multirow{2}{*}{ - } & \multirow{2}{*}{ - } & $-5.318189 * * *$ & $-5.554556^{* * *}$ \\
\hline & & & $(-11.062)$ & $(-0.9070)$ \\
\hline \multirow[t]{2}{*}{ Constant } & $-11.32021^{* * *}$ & $-12.09057^{* * *}$ & -5.134 .971 & $-15.27326^{* * *}$ \\
\hline & $(-0.9902)$ & $(-0.9557)$ & $(-41.490)$ & $(-44.284)$ \\
\hline \multicolumn{5}{|l|}{ Log(Variance) } \\
\hline \multirow[t]{2}{*}{ Constant } & $2.249149^{* * *}$ & $2.261603^{* * *}$ & $4.924474^{* * *}$ & $4.860166^{* * *}$ \\
\hline & $(-0.1187)$ & $(-0.1136)$ & $(-0.1084)$ & $(-0.1071)$ \\
\hline Observations & 10484 & 11791 & 12143 & 13559 \\
\hline
\end{tabular}

Note: Estimates for time-series cross-sectional panel data explaining federal transfers to municipalities by year. Dependent variable in models 1 and 2 takes the value of 1 if a municipality received resources from the Argentine federal housing program (EH) and 0 otherwise. Dependent variable in models 3 and 4 measures total transfer (log) for the workfare program Jefes y Jefas (PJJH)s. Random effects by municipality. Standard errors in parentheses.

$*$ = v value less/equal to 0,10 .

$*^{*}=p$ value less/equal to 0,05 .

$* * *=p$ value less/equal to 0,01 . 
While the president's decision to build $\mathrm{EH}$ alliances with governors and mayors matters, the distribution of the PJJH (models 3 and 4) follows a different pattern in which governors are the preferred intermediaries, which does not confirm the expectation regarding this transfer. At first glance, this seems surprising due to the individualized nature of this workfare program. When partisan alignments across government levels are introduced (model 4), alliances between governors and the president increase the chances of getting the PJJH by 6 times.

However, while partisan alignment between the president and mayors does not seem to determine the distribution of the PJJH, mayoral control and leverage in their municipality does, providing a more nuanced picture of the alliances behind the distribution of this transfer. When mayors are reelected, no matter their party, they significantly increase their chances of getting the PJJH. The PJJH was a highly individualized program delivered to the unemployed. Although during the first period of its assignment, the PJJH was widely publicized and there was a very short period to apply to obtain the benefits. In addition, once given the program, the chances of keeping it (or getting it on the condition that someone forfeits their spot) was highly related to closeness with the political networks, as well as to monitoring of workfare program beneficiaries by the municipality or a social organization. Regardless of their party, presidents reward reelected mayors when they can secure the distribution of the PJJH to build political support for the government.

Political control variables are significant and negatively related to the odds of getting PJJH. However, the influences of malapportionment, the effective number of parties, and the margin of victory were not significant in any case. Patterns of allocation do not seem to privilege alignment of presidents with mayors; there are governors who remain influential. But more importantly, regardless of whether mayors belong to the president's party or not, when reelected they are rewarded for the control over their constituencies and they receive more workfare program funds. 
So far we have considered how the choice of presidents' allies at subnational levels affect the distribution of two different workfare programs. It has been demonstrated that both programs are used to cement alliances with governors and mayors. However, it is not political alignment, but rather the mayors' reelections, that explain why a municipality received the PJJH. This would lead us to conclude that governors are always preferred, but what are the prospects for these different alliances? With time, alignments with governors seem to lose some of their weight. If one considers how the odds of getting the programs vary with time, one can infer that there exists a trend toward the diversification of alliances, because the $\mathrm{EH}$ (delivered both to mayors and governors) gained more influence as the years went by during the period analyzed.

PJJH began in 2002 and reached a huge number of beneficiaries in a short time. After 2011, however, it shrank and almost disappeared or was absorbed by other transfers, such as the Asignación Universal por Hijo (Bustos and Villafañe 2011). The EH followed the opposite pattern: after its outset, municipalities were more likely to get the EH and less likely to get the PJJH (the program preferred for exclusive alliances with governors). Each year shows that transfers decreased after their outset (models 2-4); however, across the years, the decrease of PJJH is notably more important than the EH. Moreover, the $\mathrm{EH}$ increased in time, particularly when considering only the mayors' party (model 1), regardless of alignment.

From all the political variables considered in model 4 , political alignments between the president and governors and the reelection of mayors are markedly the most important when explaining why a municipality gets PJJH. Although the coefficient of mayors' reelection is smaller, results are significant at $\mathrm{p}<0.01$. When alignments are included (model 4), the log-odd ratio of population increases the chances of getting the PJJH from 8 to 64. This program thus seems to be useful to build support in populated metropolitan areas where bureaucratic networks of distributions are well settled and can reach people in greater numbers than in less populated districts. On the other hand, malapportionment of provinces, mainly experienced 
by smaller districts where governors keep tight control on their politics and political networks, seems to have no influence on how presidents allocate $\mathrm{PJJH}$.

Mayoral partisanship, independent of alliances across government levels, was not a significant variable explaining the distribution of PJJH. Being a Peronist mayor doubled the chances of getting this program, but standard errors were high and the coefficient was not significant. When political coalitions are not considered, poverty is notably the most important and significant explanatory variable for odds of receiving resources from the PJJH in Argentine municipalities (model 3). Policy goals are met, as the PJJH is distributed in the poorer districts. When coalitions are excluded (model 3 ), poverty better explained $\mathrm{PJJH}$ distribution than any other variable. However, it is worth noting that when political alignments were included, the weight of poverty dropped dramatically, although poverty and unemployment remained significant and positively related to the allocation of the PJJH. Poorer districts had 360 times higher chances of getting the program (model 3); when alignments were included (model 4), these chances dropped down to 56. From the policy point of view, the very high and significant coefficient of poverty suggests the high priority given to programmatic politics, provided alignments are excluded.

Table 2 - Municipalities Receiving More Than One Single Federal Transfer

\begin{tabular}{|c|c|c|}
\hline & 5 PJHH & $6 \mathrm{PHHH}$ \\
\hline Reelected Mayor & -0.024458 & 0.0035485 \\
\hline & $(-0.0178)$ & $(-0.0181)$ \\
\hline Provincial Unemployment (lagged) & $-0.011979^{* * *}$ & $-0.0170871^{* * *}$ \\
\hline & $(-0.0036)$ & $(-0.0036)$ \\
\hline Poverty & $1.017706^{* * *}$ & $0.8285656^{* * *}$ \\
\hline & $(-0.0731)$ & $(-0.0778)$ \\
\hline Population & $0.1615515^{* *}$ & $0.4521786^{* * *}$ \\
\hline & $(-0.0742)$ & $(-0.0781)$ \\
\hline
\end{tabular}




\begin{tabular}{|c|c|c|}
\hline Other Party Mayor & 0.0228173 & \multirow{2}{*}{-} \\
\hline & $(-0.0449)$ & \\
\hline \multirow[t]{2}{*}{ Provincial Party Mayor } & $0.1091328^{* *}$ & \multirow{2}{*}{-} \\
\hline & $(-0.0458)$ & \\
\hline \multirow[t]{2}{*}{ Peronist Party Mayor } & 0.0479764 & \multirow{2}{*}{-} \\
\hline & $(-0.0347)$ & \\
\hline \multirow[t]{2}{*}{ UCR Party Mayor } & $0.123181^{* * *}$ & \multirow{2}{*}{-} \\
\hline & $(-0.0415)$ & \\
\hline \multirow[t]{2}{*}{ Year 2003} & $0.6474523^{* * *}$ & $0.6250105^{* * *}$ \\
\hline & $(-0.0254)$ & $(-0.0266)$ \\
\hline \multirow[t]{2}{*}{ Year 2004} & $0.5024792^{* * *}$ & $0.4716642^{* * *}$ \\
\hline & $(-0.0278)$ & $(-0.0285)$ \\
\hline \multirow[t]{2}{*}{ Year 2005} & $0.2634062^{* * *}$ & $0.22754^{* * *}$ \\
\hline & $(-0.0371)$ & $(-0.0380)$ \\
\hline \multirow[t]{2}{*}{ Year 2006} & 0.0374955 & -0.0150493 \\
\hline & $(-0.0480)$ & $(-0.0483)$ \\
\hline \multirow[t]{2}{*}{ Year 2007} & $-0.147846^{* * *}$ & $-0.2114518^{* * *}$ \\
\hline & $(-0.0380)$ & $(-0.0386)$ \\
\hline \multirow[t]{2}{*}{ Year 2008} & $-0.4200559^{* * *}$ & $-0.5182637^{* * *}$ \\
\hline & $(-0.0454)$ & $(-0.0442)$ \\
\hline \multirow[t]{2}{*}{ Year 2009} & $-0.8500158^{* * *}$ & $-0.9849946^{* * *}$ \\
\hline & $(-0.0473)$ & $(-0.0460)$ \\
\hline \multirow[t]{2}{*}{ Margin of Victory } & 0.0011054 & 0.000057 \\
\hline & $-(0.0007)$ & $(-0.0007)$ \\
\hline \multirow[t]{2}{*}{ ENCP } & -0.0001003 & $-0.0408586^{*}$ \\
\hline & $(-0.0240)$ & $(-0.0233)$ \\
\hline \multirow[t]{2}{*}{ Malapportionment } & -0.1314263 & $-0.3628954^{* * *}$ \\
\hline & $(-0.1044)$ & $(-0.1052)$ \\
\hline \multirow[t]{2}{*}{ Mayor Aligned with Governor } & \multirow{2}{*}{ - } & $0.1277089^{* *}$ \\
\hline & & $(-0.0501)$ \\
\hline \multirow[t]{2}{*}{ Mayor Aligned with President } & \multirow{2}{*}{ - } & 0.0080914 \\
\hline & & $(-0.0321)$ \\
\hline
\end{tabular}




\begin{tabular}{|c|c|c|}
\hline \multirow{2}{*}{ Full Alignment } & \multirow{2}{*}{ - } & $-0.2262915^{* * *}$ \\
\hline & & $(-0.0766)$ \\
\hline \multirow[t]{2}{*}{ Governor Aligned with President } & \multirow{2}{*}{ - } & -0.0018098 \\
\hline & & $(-0.0404)$ \\
\hline \multirow[t]{2}{*}{ Constant } & $5.47331^{* * *}$ & $4.238306^{* * *}$ \\
\hline & $(-0.2897)$ & $(-0.2983)$ \\
\hline Observations & 12143 & 13559 \\
\hline
\end{tabular}

Note: General Squares regression estimates for time-series cross-sectional panel data explaining federal transfers to municipalities by year. Dependent variable in models 5 and 6 measures the amount transferred (logged) for the workfare program Jefes y Jefas. Random effects by municipality. Standard errors in parentheses.

* = p value less/equal to 0,10 .

** $=p$ value less/equal to 0,05 .

$* * *=p$ value less/equal to 0,01 .

So far, it has been analyzed which variables explain the chances of a municipality getting federal funds, but once a municipality is chosen and gets the funds, what are the determinants that explain why some of them receive more resources than others? Within the municipalities receiving $\mathrm{PJJH}$ transfers, a general least square regression model for a time-series cross-sectional dataset was specified to answer this question (model 5-6).

Once municipalities obtain the PJJH, different variables explain why some receive more than others. When considering political variables, the model assessing the mayors' party (model 5) shows that opposition districts (whose mayor belongs to provincial parties or the UCR) receive more money than those belonging to the Peronist party and to the FPV. These results are consistent with the effect of alignments across government levels observed in model 6. Full political alignment between the president, governors and mayors reduces significantly the amount of funds received. This result is counterintuitive. Presidents publicly demand support from governors for their policies and political projects; for this and other reasons one would expect governors' loyalty. However, this does not seem to be the case. Full alignment means that presidents, governors and mayors belong to the PJ or the FPV (depending on the year of election). One possible explanation for this counterintuitive 
pattern is that when the party controls both governorship and municipalities, it allows presidents to reallocate more resources to opposition (potentially swing) districts once a municipality already receives the $\mathrm{PJJH}$.

This finding is consistent with the fact that the alignment between mayors and governors, excluding the president, increases the transfers received. This means that both mayors and governors do not belong to the president's party. Therefore, PJ or FPV governorships do not receive more money. When governors are allies, opposition municipalities are chosen to deliver the PJJH. The overall picture suggests that once a municipality receives the $\mathrm{PJJH}$, the decision of giving more money is related to governors' control over their polities. If governors are not able to win certain municipalities managed by opposition mayors, presidents bypass governors, delivering more PJJH money in order to increase their leverage in these districts.

Both poverty and population significantly explain the chances of getting more resources from the PJJH. However, when alignments are included, a one-unit rise in the log of population predicts a $16-45 \%$ rise in transfers. Poorer districts receive around 80-100\% more resources independently of political alignments. Malapportionment significantly reduces the money received by a municipality. Since malapportionment is also negatively related to population (over-represented districts are those with less population), this result is consistent with the positive effect that population has in model 6 on the rise of the amount of PJJH received by municipalities.

These results show that partisanship and government level variables adopt different constellations of distributive politics that do not follow a unique pattern. Instead, they vary depending on the choices of federal coalitions and the features of the public policy used to cement them. Who presidential allies are (mayors or governors) explains the variation in the distribution of different funds, even when they belong to the same party. Beyond partisanship, territorial alignments must be considered in order to understand the equilibrium between programmatic and tactical distribution. 


\section{Final remarks}

Presidents have access to resources that they can allocate with discretion, and they do not allocate them uniformly to all provinces and to all municipalities within them. Given that provincial governors are the presidents' main partners in federal countries and also that municipalities are subordinated to provinces, it was explored whether mayors also matter to explain this difference in distribution when the president allocates resources at the municipal level.

Political processes at the municipal level matter to federal democracies. Presidents seek mayors' collaboration in order to build support, recruit candidates, and deliver policies countrywide. Different practices of coalition-building with governors and mayors coexist as presidents have resources to keep both alliances and, particularly, because presidents need mayoral coalitions. This does not mean a zero-sum game with the intervention of the president in subnational politics weakening the power of governors. However, the coexistence of these federal coalitions does affect patterns of distribution.

For presidents, mayors' control of local politics allows them to address people on an individual basis, deliver federal policies, and collect votes for elections. High levels of fiscal imbalance make federal resources valuable for both governors and mayors. Even those with alternative sources of public resources understand that it is advantageous to be involved in agreements with the president for the purpose of exchanging political outcomes for federal policies and/or revenues. For governors, it is more profitable to receive money from the federal government than to raise taxes. For mayors, federal resources are an alternative to income from provinces and local taxes.

It can be verified by this article that presidents can rely simultaneously on both governors and mayors. In order to collect votes in their bureaucratic and partisan networks, both mobilize citizens to rally support and deliver national policies. It was demonstrated that presidents can simultaneously gain support from governors and mayors - as well as their bureaucratic and partisan networks - to 
collect votes, mobilize citizens in their favor, and deliver national policies.

The second finding is that the president uses specific policy tools for these collaborations, usually cemented with resources that presidents can deliver with discretion such as workfare or housing programs. The match between each resource and each subnational partner gives rise to different distributive patterns that help presidents fuel the provincial and municipal machines that guarantee political support and bureaucratic collaboration at the subnational level. For instance, in some cases it is not partisan alignment with mayors, but rather mayors' reelection, that explains distribution.

In the abundant studies on federalism, coalitions (or opposition) between governors and presidents are the best predictor for the eligibility of a municipality to receive federal rents. If one zoom into alliances, one can see that mayors are also important, but for different reasons. For instance, since housing programs are visible at the provincial level, they help governors to seek voters' support. The results of this paper show that mayors are also important for a municipality to receive resources from federal housing programs, although their influence is weaker.

Why do both matter? Houses are built by cooperatives of beneficiaries of social programs, and municipalities receive money for materials from the federal government and later distribute it. Both requirements make mayors important players for the identification of cooperative members and for the administration of the program. In the case of the workfare program, results show two counterintuitive findings. First, its individualized nature would lead us to guess that mayors are crucial for delivery. However, governors are more influential than mayors in getting this program. This first finding leads us to the second: full alignment among mayors, presidents and governors reduces the amount of money received. The workfare program is so important in collecting votes that presidents choose to bypass allied governors to reach opposition municipalities because governors were unable to win these districts. In these cases it is the reelection of mayors that explains distribution. 
This work provides evidence of the coexistence between different federal coalitions and their influence in distributive politics. Of course, neither partisan alignments nor party labels at the time of election capture the variation of alliances within parties over time. Further research is needed to address this variation and its impact on distributive politics with different proxies of federal coalitions. In addition, case studies would give us a deeper understanding of the timing of distribution and the relative weight of agreements with both governors and mayors when they coexist. In any case, results show that programmatic and distributive politics explain which municipalities are chosen and how much money is delivered to them. Along with federal coalitions, social variables explain patterns of distribution, suggesting that the use of income support transfers to allied mayors does not hinder the achievement of policy goals. Since there are more potential beneficiaries than public resources available within eligible districts, coalitions explain distribution. This equilibrium between programmatic and political distribution varies depending on presidential partners and the type of goods delivered. This variation should be studied in depth; in developing countries, it is at the heart of the state's success to respond to the basic needs of citizens.

\section{References}

ALBERTUS, Michael; DIAZ-CAYEROS, Alberto; MAGALONI, Beatríz; WEINGAST, Barry Robert. Authoritarian survival and poverty traps: Land reform in Mexico. World Development v. 77, p. 154-170, 2015.

ARDANAZ, Martín; LEIRAS, Marcelo; TOMMASI, Mariano. The Politics of Federalism in Argentina and its Effects on Governance and Accountability. World Development, v. 53, p. 26-45, 2014.

AUYERO, Javier. La política de los pobres: las prácticas clientelistas del peronismo. Buenos Aires: Manantial, 2001.

BEHREND, Jacqueline. The Unevenness of Democracy at the Sub-National Level: Provincial Closed Games in Argentina. Latin American Research Review, v. 46, n. 1, p. 150-176, 2011. 
BERAMENDI, Pablo; ROGERS, Melissa; DÍAZ-CAYEROS, Alberto. Barriers to Egalitarianism: Distributive Tensions in Latin American Federations. Latin American Research Review, v. 52, n. 4, p. 529-551, 2017.

BLAND, Gary. Considering Local Democratic Transition in Latin America. Journal of Politics in Latin America v. 3, n. 1, p. 65-98, 2011.

BOHN, Simone. Social Policy and Vote in Brazil. Latin American Research Review, v. 46, n.1, 2011.

BORGES, André. The Political Consequences of Center-Led Redistribution in Brazilian Federalism the Fall of Subnational Party Machines. Latin American Research Review, v. 46, n. 3, p. 21-45, 2011.

BORGES, André; LLOYD, Ryan. Presidential coattails and electoral coordination in multilevel elections: comparative lessons from Brazil. Electoral Studies, v. 43, p. 104-114, 2016.

BOULDING, Carew; BROWN, David. Political competition and local social spending: evidence from Brazil. Studies in Comparative International Development, v. 49, n. 2, p. 197-216, 2013.

BUSTOS, Juan Martín; VILLAFANE, Soledad. Asignación universal por hijo. Evaluación del impacto en los ingresos de los hogares y el mercado de trabajo. Trabajo, ocupación y empleo._ Buenos Aires: MdTSS, 2011.

CALVO, Ernesto; MOSCOVICH, Lorena. Inequality, Protests, and the Progressive Allocation of Cash Transfers in the Argentine Provinces. Latin American Politics and Society, v. 59, p. 3-26, 2017.

CALVO, Ernesto; MURILlO, María Victoria. When Parties Meet Voters: Assessing Political Linkages through Partisan Networks and Distributive Expectations in Argentina and Chile. Comparative Political Studies, v. 46, n. 7, p. 851:882, 2013. . Who Delivers? Partisan Clients in the Argentine Electoral Market. American Journal of Political Science, v. 48, p. 743-757, 2004. 
CAMP, Edwin; SZWARCBERG, Mariela. Competitive Clientelism. Meeting of the Midwest Political Science Association. Chicago, IL, 2015.

CAO, Horacio. La administración pública argentina: nación, provincias y municipios. XIII CLAD. Buenos Aires, 2008.

CARSON, Jamie; ROBERTS, Jason; BOX-STEFFENSMEIER, Janet; CANON, David. Ambition, Competition, and Electoral Reform: The Politics of Congressional Elections Across Time. Ann Harbor: Michigan Publishing, 2013.

CHIARA, Magdalena; DI VIRGILIO, María Mercedes . Gestión Social y municipios. De los escritorios del Banco Mundial a los barrios del Gran Buenos Aires. Buenos Aires: Prometeo, 2005.

CINGOLANI, Mónica; MAZZALAY, Víctor; NAZARENO, Marcelo. Política electoral y distribución territorial del gasto en Córdoba, 1999-2003. Studia Politicae, v. 12, p. 62-64, 2007.

DE LUCA, Miguel. Political Recruitment and Candidate Selection in Argentina: Presidents and Governors, 1983 to 2006. In: SIAVELIS, Peter; MORGENSTERN, Scott. Pathways to Power. Political Recruitment and Candidate Selection in Latin America. University Park: Penn State Press, 2008.

DICKOVICK, James Tyler. Federalism in Africa: Origins, Operation and (In) Significance. Regional \& Federal Studies, v. 24, n. 5, p. 553-570, 2014.

. Municipalization as Central Government Strategy: CentralRegional-Local Politics in Peru, Brazil, and South Africa. Publius The Journal of Federalism, v. 37, n. 1, p. 1-25, 2007.

DICKOVICK, James Tyler; EATON, Kent. Latin America's Resurgent Centre: National Government Strategies after Decentralisation. The Journal of Development Studies, v. 49, n. 11, p. 1-14, 2013.

EATON, Kent. Politics beyond the Capital. The Design of Subnational Institutions in South America. Cambridge: Cambridge University Press, 2004. 
FENWICK, Tracy Beck. The Institutional Feasibility of NationalLocal Policy Based Collaboration: Insights from Brazil and Argentina. Journal of Politics in Latin America, v. 2, p. 155-183, 2010.

Avoiding Governors: The Success of Bolsa Familia. Latin American Research Review v. 44, n. 1, p. 102-131, 2009.

FREILLE, Sebastián; CAPELLO, Marcelo. Electoral effects of intergovernmental fiscal transfers: An application to local elections in the province of Cordoba, 1995-2011. Revista de economía y estadística, v. 52, n. 1, p. 113-135, 2014.

GARAY, Candelaria. Social Policy and Collective Action: Unemployed Workers Community Associations, and Protest in Argentina. Politics and Society, v. 35, n. 2, p. 301-328, 2007.

GERVASONI, Carlos. A Rentier Theory of Subnational Regimes. Fiscal Federalism, Democracy, and Authoritarianism in the Argentine Provinces. World Politics, v. 62, n. 2, p. 302-40, 2010.

GIBSON, Edward; CALVO, Ernesto. Federalism and Low-Maintenance Constituencies: Territorial Dimensions of Economic Reforms in Argentina. Studies in Comparative International Development, v. 35, n. 3, p. 32-55, 2000.

GIRAUDY, Agustina. The Distributive Politics of Emergency Employment Programs in Argentina (1993-2002). Latin American Research Review, v. 42, n. 2, p. 33-55, 2007.

GOMEZ, Eduardo. Decentralization and Municipal Governance: Suggested Approaches for Cross- Regional Analysis. Studies in Comparative International Development, v. 38, n. 3, p. 57-80, 2003.

GONZÁLEZ, Lucas. Electoral Competition and Social Spending in the Argentine province. Journal of Politics in Latin America v. 9, n. 1, p. 91-124, 2017.

. Presidents, Governors, and the Politics of Distribution in Federal Democracies: Primus Contra Pares in Argentina and Brazil. New York: Routledge, 2016. 
GORDIN, Jorge. Patronage-Preserving Federalism?: Legislative Malapportionment and Subnational Fiscal Policies. In: ERK, Jan; SWENDEN, Wilfied. Exploring New Avenues in Comparative Federalism. London: Routledge, 2010.

HISKEY, Jonathan. The Return of "The Local" to Mexican Politics. In: AI CAMP, Roderic (Ed.), The Oxford Handbook of Mexican Politics. Oxford: Oxford University Press, 2012.

HUNTER, Wendy; POWER, Timothy. Rewarding Lula: Executive Power, Social Policy, and the Brazilian Elections of 2006. Latin American Politics and Society, v. 49, n. 1, p. 1-30, 2007.

IARAF. Alerta: caen ya $13 \%$ los ingresos de provincias. Retrieved from: http://www.iaraf.org/index.php/2014-08-18-21-38-34/ repercusiones/69-alerta-caen-ya-13-los-ingresos-de-provincias. Accessed February 2016, 2015.

JONES, Mark; TOMMASI, Mariano; SANGUINETTI, Pablo. Politics, Institutions and Fiscal Performance in a Federal System: An Analysis of the Argentine Provinces. Buenos Aires: Fundación Gobierno y Sociedad, 1998.

LAAKSO, Markku; TAAGEPERA, Rein. Effective Number of Parties: A Measure with Application to West Europe. Comparative Political Studies, v. 12, n. 1, p. 3-28, 1979.

LEE, Frances. Geographic Politics in the U.S. House of Representatives: Coalition Building and Distribution of Benefits. American Journal of Political Science, v. 47, n. 4, p. 714-728, 2003. LEIRAS, Marcelo; TUÑ́N, Guadalupe; GIRAUDY, Agustina. Who Wants an Independent Court? Political Competition and Supreme Court Autonomy in the Argentine Provinces (19842008). The Journal of Politics, v. 77, n. 1, p. 175-187, 2014.

LODOLA, Germán. La estructura subnacional de las carreras políticas en Argentina y Brasil. Desarrollo Económico, v. 49, n. 194, p. 247-286, 2009.

Protesta popular y redes clientelares en la Argentina: El reparto federal del Plan Trabajar (1996-2001). Desarrollo Económico, v. 44, n. 176, p. 515-536, 2005. 
MACKINNON, Moira. Los años formativos del partido peronista. Buenos Aires: Instituto Di Tella - Siglo XXI, 2002.

MACOR, Darío; TCACH, César (Eds.). La invención del peronismo en el interior de país. Santa Fé: Universidad Nacional del Litoral, 2003.

MELONI, Osvaldo. Budget Manipulation and Vertical Fiscal Imbalance. Toronto: LASA Conference, 2010.

MEREDITH, Mark. Exploiting Friends-and-Neighbors to Estimate Coattail Effects. University of Pennsylvania, manuscript, 2011.

MONTERO, Alfred; SAMUELS, David. The Political Determinants of Decentralization in Latin America. Causes and consequences. In: MONTERO, Alfred; SAMUELS, David. Decentralization and Democracy in Latin America. Notre Dame: University of Notre Dame Press, 2004.

MOSCOVICH, Lorena. From top to bottom (and back to the top again): Federal Spending, Sub-national Coalitions, and Protests in Argentina, 2002-2006. Journal of Politics in Latin America, v. 4, n. 1, p. 35-72, 2012.

. Estado y sociedad civil en el Gran Buenos Aires. Cambio $\mathrm{y}$ tensiones en las nuevas relaciones de gobierno local. In: CIMADAMORE, Alberto (Ed.). La economía política de la pobreza. Buenos Aires: Clacso, 2008.

MTSS Programa Jefes de Hogar. Informe Resumen. Plan Integral de Promoción del Empleo. Buenos Aires: Ministerio de Trabajo, Empleo y Seguridad Social, 2009.

NAZARENO, Marcelo; STOKES, Susan; BRUSCO, Valeria. Réditos y peligros electorales del gasto público en la Argentina. Desarrollo Económico, v. 46, n. 181, p. 63-88, 2006.

NICKSON, Andrew. Where Is Local Government Going in Latin America? A Comparative Perspective. International Centre for Local Democracy, Working Paper n. 6, p. 1-36, 2011.

NIEDZWIECKI, Sara. Social Policies, Attribution of Responsibility, and Political Alignments a Subnational Analysis of Argentina and Brazil. Comparative Political Studies v. 18, 2015. 
O'NEILL, Kathleen. Decentralizing the State: Elections, Parties, and Local Power in the Andes. New York: Cambridge University Press, 2005.

PÍREZ, Pedro. Municipio, Necesidades Sociales y política local. Buenos Aires: Grupo editor latinoamericano, 1991.

PORTO, Alberto; PORTO, Natalia. Fiscal Decentralization and Voters' Choices as Control. Journal of Applied Economics, v. 3, n. 1, p. 135-167, 2000.

PORTO, Alberto; SANGUINETTI, Pablo. Political Determinants of Intergovernmental grants: Evidence from Argentina. Economics and Politics 13(3), 2001.

POSNER, Daniel; KRAMOR, Eric. Who Benefits from Distributive Politics? How the Outcome One Studies Affects the Answer One. Perspective of Politics, v. 11, n. 2, p. 461-474, 2013.

SAMUELS, David. Reinventing Local Government? Municipalities and Intergovernmental Relations in Democratic Brazil. In: KINGSTON, Peter; POWER, Timothy (Eds.). Democratic Brazil. Actors, Institutions, and Processes. Pittsburgh: Pittsburgh University Press, 2000.

. Ambition, Federalism, and Legislative Politics in Brazil. New York: Cambridge University Press, 2003.

SAMUELS, David; SNYDER, Richard. La desproporcionalidad territorial. In: CALVO, Ernesto; ABAL MEDINA (h), Juan Manuel (Eds.). El federalismo electoral argentino. Sobrerrepresentación, reforma política y gobierno dividido en la Argentina. Buenos Aires: EUDEBA, 2001.

SAMUELS, David; MAINWARING, Scott. Strong Federalism, Constraints on the Central Government, and Economic Reform in Brazil. In: GIBSON, Edward Gibson (Ed.). Federalism and Democracy in Latin America. Baltimore: John Hopkins University Press, 2004.

SEELE, Andrew. Municipalities and Policymaking. In: AI CAMP, Roderic (Ed.). The Oxford Handbook of Mexican Politics. Oxford: Oxford University Press, 2012. 
SIN, Gisela; PALANZA, Valeria. Partidos provinciales y gobierno nacional en el Congreso (1983-1995). Boletín de la Sociedad Argentina de Análisis Político, v. 5, p. 46-94, 1997.

SOUZA, Celina. Breaking the Boundary: Pro-poor Policies and Electoral Outcomes in Brazilian Sub-national Governments. Regional and Federal Studies, v. 25, n. 4, p. 347-363, 2015.

STOKES, Susan; DUNNING, Thad; NAZARENO, Marcelo; BRUSCO, Valeria. Buying Votes: Distributive Politics in Democracies. New York: Cambridge, 2013.

SZWARCBERG, Mariela. The Microfoundations of Political Clientelism. Lessons from the Argentine Case. Latin American Research Review, v. 48, n. 2, p. 32-54, 2013.

TOMMASI, Mariano. Federalism in Argentina and the Reforms of the 1990s. Documento de trabajo No48. Victoria: Universidad de San Andrés, 2002.

TORRE, Juan Carlos. Los huérfanos de la política. Sobre los alcances y naturaleza de la crisis de representación partidaria. Desarrollo Económico, v. 42, n. 168, p. 647-665, 2003.

WEINGAST, Barry. Second generation fiscal federalism: Political aspects of decentralization and economic development. World Development, v. 53, p. 14-25, 2015.

WEITZ-SHAPIRO, Rebecca. What Wins Votes: Why Some Politicians Opt Out of Clientelism. American Journal of Political Science, v. 56, n. 3, p. 568-583, 2012.

WIBBELS, Erik. Decentralized governance, constitution formation, and redistribution. Constitutional Political Economy, v. 16, n. 2, p. 161-188, 2005.

ZARAZAGA, Rodrigo. Brokers Beyond Clientelism: A New Perspective Through the Argentine Case. Latin American Politics and Society, v. 56, n. 3, p. 23-55, 2014.

ZUCCO, César. Cash-transfers and voting behavior: An empirical assessment of the political impacts of the Bolsa Familia program. Toronto: American Political Studies Association annual meeting, 2009. 


\section{. The President's 'New' Constituency: Lula and the Pragmatic}

Vote in Brazil's 2006 Presidential Elections. Journal of Latin American Studies, v. 40, n. 1, p. 29, 2008.

\section{Appendix A}

\begin{tabular}{|c|c|c|}
\hline Variable & Definition & Source \\
\hline $\begin{array}{l}\text { Got PJJH (Dependent } \\
\text { variable in models } 3 \text { and } 4 \text { ) }\end{array}$ & $\begin{array}{l}\text { Got PJJH is a dichotomous variable taking the value of } 1 \text { if a muni- } \\
\text { cipality in a particular year obtains a transfer from the Jefes y Jefas } \\
\text { de Hogar program (Household Heads Program) and } 0 \text { otherwise. }\end{array}$ & $\begin{array}{l}\text { Sub Secretary of Employment } \\
\text { of the Ministry of Labor }\end{array}$ \\
\hline $\begin{array}{l}\text { Got EH (Dependent variable } \\
\text { in models } 1 \text { and 2) }\end{array}$ & $\begin{array}{l}\text { Got EH is a dichotomous variable taking the value of } 1 \\
\text { if a municipality in a particular year gets a transfer from } \\
\text { the Programa de Emergencia Habitacional (Federal } \\
\text { Housing Emergency Program) and Ootherwise }\end{array}$ & $\begin{array}{l}\text { Sub secretary of Urban } \\
\text { Development and Housing of } \\
\text { the Ministry of Federal Planning, } \\
\text { Public Investment and Services. }\end{array}$ \\
\hline $\begin{array}{l}\text { LPJJH (Dependent Variable } \\
\text { in Models } 5 \text { and } 6 \text { ) }\end{array}$ & $\begin{array}{l}\text { A federal workfare programs given to each } \\
\text { municipality each year, logged }\end{array}$ & $\begin{array}{l}\text { Sub Secretary of Employment } \\
\text { of the Ministry of Labor. }\end{array}$ \\
\hline Reelected Mayor & $\begin{array}{l}\text { A dichotomous variable taking the value of } 1 \text { if a } \\
\text { mayor has been reelected or otherwise } 0\end{array}$ & Ministry of Interior \\
\hline Provincial Unemployment & Percentage of poor people by province per year (lagged) & $\begin{array}{l}\text { INDEC, National Hou- } \\
\text { se Survey (EPH) }\end{array}$ \\
\hline Poverty & $\begin{array}{l}\text { Percentage of people with basic unsatisfied needs (NBI) by } \\
\text { municipality in 2001, for last available census data 2001, logged }\end{array}$ & $\begin{array}{l}\text { National Institute of Statistics } \\
\text { and } 2001 \text { Census (INDEC) }\end{array}$ \\
\hline Population & Number of people living in each municipality in 2001, logged. & $\begin{array}{l}\text { National Institute of Statistics } \\
\text { and } 2001 \text { Census (INDEC) }\end{array}$ \\
\hline
\end{tabular}




\begin{tabular}{|c|c|c|}
\hline Provincial party mayor & $\begin{array}{c}\text { A dichotomous variable taking the value of } 1 \text { if the ma- } \\
\text { yor belongs to a provincial party or otherwise 0 } \\
\text { electoral alliance which has only run at provincial level, } 0 \text { otherwise }\end{array}$ & Ministry of Interior \\
\hline Peronist party mayor & $\begin{array}{c}\text { A dichotomous variable taking the value of } 1 \text { if the ma- } \\
\text { yor belongs to the Peronist party or otherwise } 0\end{array}$ & Ministry of Interior \\
\hline UCR party mayor & $\begin{array}{c}\text { A dichotomous variable taking the value of } 1 \text { if the mayor } \\
\text { belongs to the Union Cívica Radical Party (UCR) or otherwise 0 }\end{array}$ & Ministry of Interior \\
\hline $\begin{array}{c}\text { Mayor aligned with } \\
\text { the Governor }\end{array}$ & $\begin{array}{c}\text { A dichotomous variable taking the value of } 1 \text { if the mayor } \\
\text { and governors belong to the same party or otherwise 0 }\end{array}$ & Ministry of Interior \\
\hline $\begin{array}{c}\text { Mayor aligned with } \\
\text { the President }\end{array}$ & $\begin{array}{c}\text { A dichotomous variable taking the value of } 1 \text { if the mayor } \\
\text { and president belong to the same party or otherwise } 0\end{array}$ & Ministry of Interior \\
\hline $\begin{array}{c}\text { Governor aligned } \\
\text { with the President }\end{array}$ & $\begin{array}{c}\text { A dichotomous variable taking the value of } 1 \text { if the governor } \\
\text { and president belong to the same party or } 0 \text { otherwise }\end{array}$ & Ministry of Interior \\
\hline
\end{tabular}

\section{Summary Statistics}

\begin{tabular}{|c|c|c|c|c|c|c|}
\hline Variable & Obs & Mean & Std. Dev. & Min & Max & Coef. Var. \\
\hline (log) EH & 15503 & 95012 & 353566 & 0 & 9392745 & 3.721 \\
\hline (log) PJJH & 17720 & 2054297 & 2735651 & 0 & 9998843 & 1.332 \\
\hline $\begin{array}{c}\text { (log) Population } \\
\text { Poverty (lagged) }\end{array}$ & 16449 & 6022952 & 2864254 & 5826 & 9990078 & 0.476 \\
\hline $\begin{array}{c}\text { Reelected Mayor } \\
\text { Mayor aligned with } \\
\text { the governor }\end{array}$ & 16931 & 0.511 & 0.500 & 0 & 1 & 0.978 \\
\hline
\end{tabular}




\begin{tabular}{|c|c|c|c|c|c|c|}
\hline $\begin{array}{c}\text { Mayor aligned with } \\
\text { the president }\end{array}$ & 17720 & 0.478 & 0.500 & 0 & 1 & 1.045 \\
\hline Full alignment & 17720 & 0.266 & 0.442 & 0 & 1 & 1.660 \\
\hline $\begin{array}{c}\text { Governor aligned with } \\
\text { the president }\end{array}$ & 17720 & 0.455 & 0.498 & 0 & 1 & 1.095 \\
\hline \begin{tabular}{c} 
GotPJJH (dummy) \\
\hline Got EH (dummy)
\end{tabular} & 177720 & 0.913 & 0.282 & 0 & 1 & 0.310 \\
\hline Margin of victory & 17720 & 17.325 & 17.433 & 0.78 & 84.54 & 1.006 \\
\hline Effective Number of Parties & 17720 & 2.579 & 0.658 & 1.22 & 4.45 & 0.255 \\
\hline Malapportionment & 17712 & -0.157 & 0.434 & -0.791 & 1.744 & -2.763 \\
\hline
\end{tabular}

\section{Abstract}

Governors and mayors contribute with necessary political inputs to federal politics, and the president may have no incentive or choice to exclude any of them from their alliances. When presidents have money to distribute with discretion, they do not allocate it uniformly; there are differences in funds allocated between and within provinces, as well as different municipalities within them. The objective of this paper is to explain these differences and particularly how this distribution works in countries where municipalities are not autonomous and the president cannot bypass governors. Transfer distribution patterns at two municipal levels will be explored in order to show that partisan alignments between mayors and presidents (along with other political variables, such as mayors being up for reelection) can be analyzed to explain differences in funding levels.

The new generation of studies on federalism focuses on different variables, beyond the functioning of formal institutions. Within these variables, the role of governors - namely the fact that they are powerful and important to presidents - has been widely documented by scholarly research. However, the role of mayors has been less thoroughly explored. 
To generate evidence on how both governors and mayors are important to presidents, it was built an original database that, for the first time, studied distribution in all Argentine municipalities for a period of eight years (2002-2009) to help fill this vacuum.

Keywords: Distributive Politics; Federalism; Elections., Presidencialism.

Recebido em 20 de Outubro de 2017

Aprovado em 20 de Abril de 2018 